\title{
BLACKTAIL PRAIRIE DOG EMMIGRATION STUDY, BADLANDS NATIONAL PARK, SOUTH DAKOTA
}

\author{
R. M. Hansen \\ R. P. Cincotta \\ Department of Range Science \\ Colorado State University
}

\section{Introduction}

The blacktail prairie dog (Cynomys ludovicianus) has evolved as a highly successful colonial herbivore with a definite role among natural prairie ecosystems (Coppock et al., 1980; McHugh, 1958). Their coloniality often creates high population densities and heavy use of vegetation (Klatt, 1971; Koford, 1958), inviting conflict with human land use. Exercising management extremes (i.e., completely exterminating prairie dog colonies or allowing the propogation of hugh populations) appears to present little difficulty. The necessary alternative of containing colonial areas and controlling population densities, however, will require nothing short of a complete understanding of prairie dog emigration ecology.

Three basic types of prairie dog movement are possible: movements within towns, peripheral expansion of established towns, and long distance dispersals. The latter two categories are of most practical interest, though the amount of within group recruitment must surely exert some influence upon town expansion and dispersal. The subject has received little or no attention in the literature. Expansion of town perimeters and long distance dispersals appear as quite different phenomena. Observations on Badlands N.P. dog towns suggest that establishment of peripheral burrows rarely occurs over 50 meters from an existing burrow system. Long distance dispersals appear, however, as less common, less successful events which bring individuals into other populations or initiate new colonies. Blacktail prairie dogs have been located over four miles from existing towns (Smith, 1958).

Expansion along town peripheries has been described as both an early springtime activity (King, 1955; Koford, 1958; Smith, 1958) and an autumnal activity (Costello, 1970). Little agreement, and less data, exists upon the structure of these emigrating individuals; and only speculation is responsible for our present notions about the variables which control this movement.

Three specific models of prairie dog emigration can be put forth:

1. Blacktail prairie dog coloniality is primarily a defensive strategy (Hoogland, 1981); and therefore, peripheral emigration patterns 
must help to increase defensive efficiency and maintain communication among individuals. Visibility between burrows and between foraging areas and burrows is most critical.

2. Blacktail prairie dogs are highly territorial mammals (King, 1955) which form territorial groups (coiteries) within towns as a basis for social interactions. Therefore, it is population dependent social pressures which direct emigration patterns. Within-group and between-group population structure influences the degree and direction of peripheral dog town expansion. Increasing territorial demands, corresponding directly to age and size of the individual, underlie the formation of new groups and the expansion or deterioration of old group territories.

3. Blacktail prairie dogs have a great effect upon the amount and composition of vegetation within the colony (Fagerstone et al., 1981; Gold, 1976; Klatt, 1971). The combined effects of certain ungulates (such as bison and cattle) augment grazing pressure changes caused by prairie dogs because of the high degree of dietary overlap with prairie dogs. Changes in carrying capacity eventually drive emigration of individuals to areas of greater or more preferred forage resources. Emigration patterns are, therefore, related to diet preferences and vegetational availability inside and outside group territories.

A fourth more general model appears more plausible:

4. All of the above emigration models are considerations in prairie dog emigration ecology. Each may contribute to emigration patterns, though the relative importance of these submodels may vary; i.e., defense, soils, and vegetational structure may dictate the direction and extent of town expansion until a point where territorial pressures override these considerations.

\section{Objectives}

The project objectives are: 1) to study prairie dog emigration in respect to the four models listed above; 2) to study natural immigration onto uncolonized rangeland within park boundaries; and 3) to study immigration onto sites of prairie dog extermination adjacent to the park.

\section{Methods}

Data collection is based upon a modular approach; i.e., the division of peripheral dog town areas into 25 meter grids and the measurement of important variables such as vegetational frequency and biomass, soils, and visibility at animal height (estimated by sighting upon a target). Modules can then be grouped according to their original similarities 
and responses during analysis. Grids have also been extended outside the town to detect changes as prairie dogs immigrate into these areas. Capture and release is also being done in reference to these grids. The location of burrows within the grids have been mapped to accurately detect patterns, dates, and individuals involved in expansion.

Plans have been made to collect prairie dog fecal matter in the coming year to be used in determining seasonal food habits through microhistological analysis (Storr, 1961). It is hoped that seasonal food habits data coupled with that of soils and vegetational and prairie dog populational structures will provide additional information concerning the effect of vegetation on blacktail prairie dog emigration.

\section{Results}

Results of vegetation sampling in 1981 indicate the occurrence of sudden changes in plant composition due to an increase in prairie dog densities (Figure 1). Many of the forbs, such as fringed sage (Artemesia frigida) and russian thistle (Salsola kali) which were present on heavily grazed portions of the dog town periphery during August, had been completely ignored as forage. Others, including scarlet globemallow (Sphaeralcea coccinea) and slimleafed goosefoot (Chenopodium leptophyllum), remained only lightly grazed. Fagerstone, et al., (1981) found that forbs which were not selected during the spring and fall often became important during the winter, concurrent with decline in overall availability of total forage and loss of moisture among grasses. Therefore, populated areas which are less attractive at the termination of the growing season may once again become suitable during the winter. This could partly account for the return of individuals from town perimeters to more interior burrows during winter, as witnessed by Koford (1958) and Smith (1958).

A total of 264 blacktail prairie dogs have been captured, weighed, sexed, marked, and released during the 1981 field season. The continued identification and location of these and new individuals over three years will be necessary to detect any overall emigration patterns. A relationship $\left(r^{2}=.54\right)$ exists between individual territory size and body weight (Figure 2) within territorial groups (coiteries). The growth of juveniles may, therefore, produce the type of between-group conflicts and within-group competition which is responsible for expansion of towns during the autumn.

\section{Literature Cited}

Coppock, D. L., J. K. Detling, and M. I. Dyer. 1980. Interactions among bison, prairie dogs, and vegetation in Wind Cave National Park. Nat. Res. Ecol. Lab., Colorado State University, Fort Collins, Co. $177 \mathrm{pp}$. 


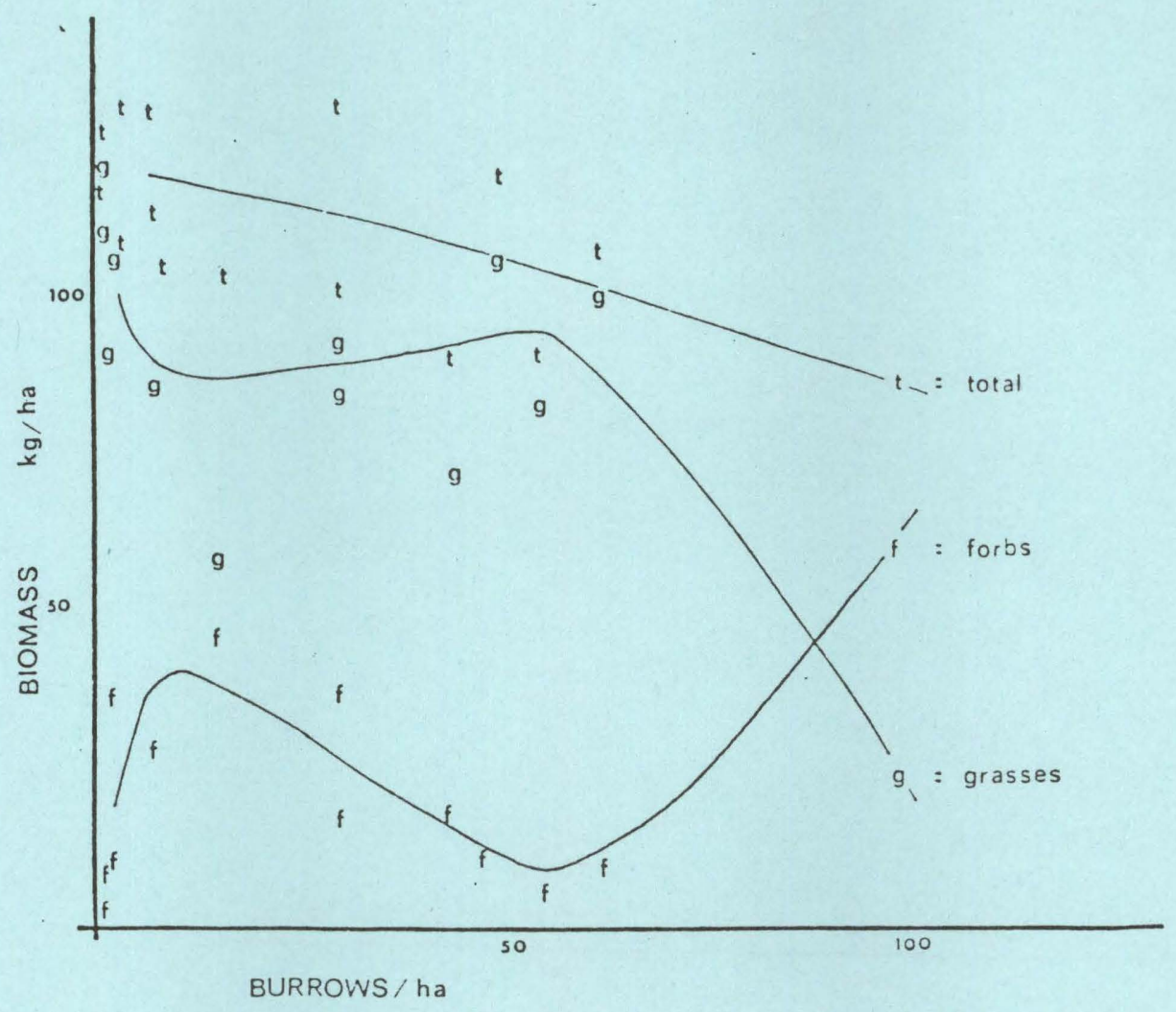

Figure 1. Prairie dog town vegetational relationships. 


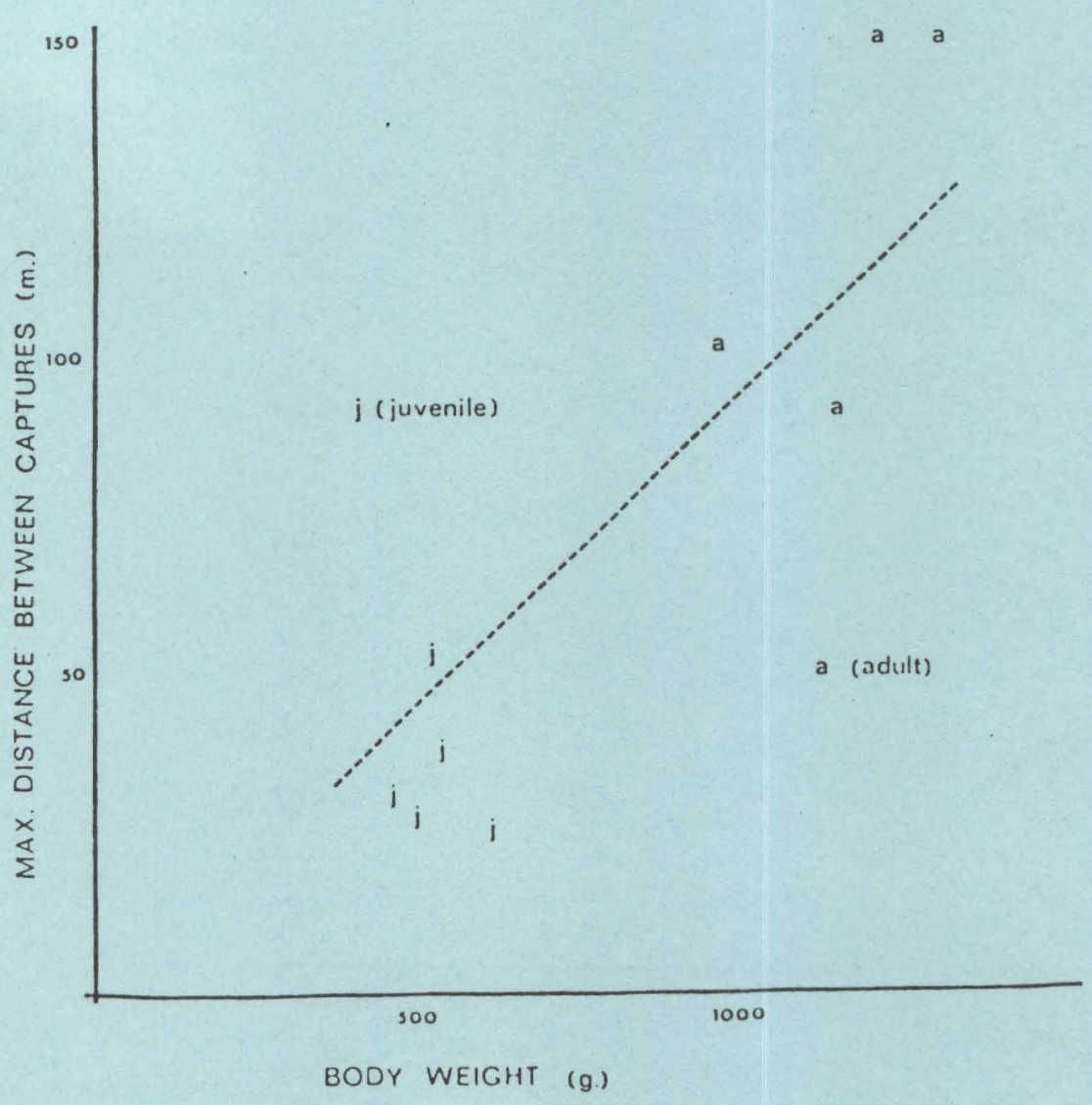

Figure 2. Within-group territorial relationships among juveniles and adults in a coiterie on Hockings dog town, Badlands N.P. 
Costello, D. F. 1970. The world of the prairie dog. J. B. Lippincott Co., Philadelphis. 160 pp.

Fagerstone, K. A., H. P. Tietjen, and 0. Williams. 1981. Seasonal variation in the diet of black-tailed prairie dogs. J. Mamm., $62(4): 820-824$.

Gold, I. K. 1976. Effects of prairie dog mounds on shortgrass vegetation. M.S. Thesis, Colorado State University, Fort Collins, Co. $92 \mathrm{pp}$.

Hoogland, J. L. 1981. The evolution of coloniality in white-tailed and black-tailed prairie dogs (Sciuridea: Cynomys leucurus and c. ludovicianus). Ecology, 62(1): 252-272.

King, John A. 1955. Social behavior, social organization, and population dynamics in a black-tailed prairie dog town in the Black Hills of South Dakota. Contributions from the Lab. of Vert. Biol., No. 67, Univ. of Ml.

Klatt, L. E. 1971. A comparison of the ecology of active and abandoned black-tailed prairie dog (Cynomys ludovicianus) towns. M.S. Thesis, Colo. State University, Fort Collins, C0. $66 \mathrm{pp}$.

McHugh, T. 1958. Social behavior of the American buffalo (Bison bison bison). Zooligica, 43(1): 1-40.

Smith, R. E. 1958. Natural history of the prairie dog in Kansas. Mus. of Nat. Hist., No. 16, Univ. of Kansas.

Storr, G. M. 1961. Microscopic analysis of faeces, a technique for ascertaining the diet of herbivorous mammals. Australian J. Biol. Sci., 14: 157-164. 